\title{
VIABILITY OF MYCOPLASMAS AFTER STORAGE IN FROZEN OR LYOPHILISED STATES
}

\author{
Jean P. Addey, D. Taylor-Robinson and Mileva Dimic* \\ MRC Clinical Research Centre, Harvard Hospital, Salisbury, Wiltshire
}

Ir is known that mycoplasmas may be preserved in the frozen state, although there is only one report (Kelton, 1964) concerning the viability of a variety of mycoplasmas after their long-term storage. In this laboratory, cultures of many prototype strains and other strains of mycoplasmas have been prepared for routine use. These have been stored at $-70^{\circ} \mathrm{C}$, and some have been stored also at $-50^{\circ} \mathrm{C}$ and $-30^{\circ} \mathrm{C}$. In order to store numerous stock cultures economically, a micro-system with storage in plastic trays has been used. The viability of some mycoplasmas stored in this way has been compared with their viability after storage in glass vials. Some cultures of mycoplasmas have also been lyophilised in order to facilitate transport to other laboratories. At various intervals over a period of at least $2 \mathrm{yr}$, samples of all these frozen and lyophilised cultures have been titrated for their content of viable organisms and the results are presented in this communication.

\section{MATERIALS AND METHODS}

Mycoplasmas. The organisms studied in most detail were recognised strains of mycoplasmas isolated from both avian and mammalian sources. Their origin and other details have been described previously (Manchee and Taylor-Robinson, 1968; Taylor-Robinson, Williams and Haig, 1968).

Media. The mycoplasmas were grown in a liquid medium composed of $70 \mathrm{ml}$ Difco " PPLO " broth, $20 \mathrm{ml}$ unheated Burroughs Wellcome horse serum no. 6, $10 \mathrm{ml}$ of a 2.5 per cent. (w/v) aqueous extract of dried yeast (Distillers Co. Ltd), $2 \mathrm{ml}$ of a 2.5 per cent. aqueous solution of thallium acetate ( $1 \mathrm{ml}$ only for T-strain mycoplasmas), $1 \mathrm{ml}$ of a solution containing 100,000 units of penicillin $\mathrm{G}$, and $2 \mathrm{ml}$ of a $0 \cdot 1$ per cent. aqueous solution of phenol red. Depending upon the mycoplasmas under study, glucose, arginine or urea was added to this basic medium to a final concentration of $0 \cdot 1$ per cent. Medium containing glucose was adjusted to $p \mathrm{H} \mathrm{7.8}$ and media containing arginine or urea to $p \mathrm{H} \mathrm{7.0.} \mathrm{Solid} \mathrm{medium} \mathrm{was}$ prepared by the addition of 1 per cent. agar (Oxoid Ionagar no. 2 or Agar no. 1) to the PPLO broth before the other ingredients were added.

Titration of viable organisms. Serial 10 -fold dilutions were made in medium contained in vials of $c .2 \mathrm{ml}$ with screw caps and rubber liners (Anchor Glass Co. Ltd, London). Each of the mycoplasmas metabolises glucose, arginine or urea so that growth in medium with the appropriate substrate alters the $p \mathrm{H}$ and this changes the colour of the phenol red in the medium. Vials were incubated at $36^{\circ} \mathrm{C}$ until colour changes were complete. The highest dilution at which a colour change occurred was the end-point of the titration. Sometimes the test organism was seeded on solid medium and incubated in a humidified atmosphere of

Received 2 June 1969; accepted 1 Aug. 1969.

* World Health Organization Fellow from The Institute of Pharmacology, Belgrade, Yugoslavia.

J. MED. MICROBIOL.-VOL. 3 (1970) 
5 per cent. $\mathrm{CO}_{2}(\mathrm{v} / \mathrm{v})$ and 95 per cent. $\mathrm{N}_{2}(\mathrm{v} / \mathrm{v})$ at $37^{\circ} \mathrm{C}$. Colonies were counted after they ceased to increase in number.

Storage in plastic trays. For routine use, mycoplasmas were stored frozen in Linbro S-MRC-96 thin plastic Disposo-trays (Linbro Chemical Co. Inc., New Haven, Connecticut, USA). The method of storage and retrieval is shown in the figure. The vertical edges of the trays were cut off and the cup-containing portions subjected to ultraviolet irradiation. The cultures were then dispensed in $0.1-\mathrm{ml}$ amounts per cup with a boiled $0.025-\mathrm{ml}$ pipette

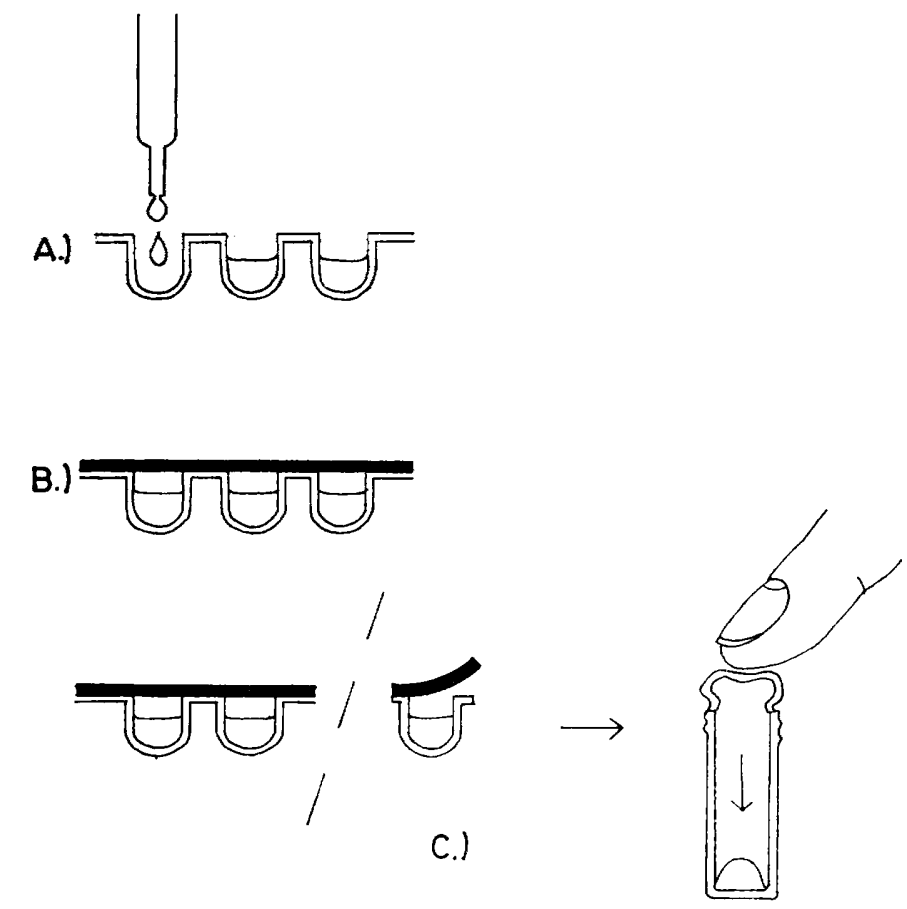

FIGURE.-Storage of mycoplasma culture in and retrieval from Linbro S-MRC-96 Disposo-trays. A. Four drops, each of $0.025 \mathrm{ml}$ of mycoplasma culture, are placed in each cup. B. Tray sealed with adhesive tape and stored at $-70^{\circ} \mathrm{C}$. C. Cup cut away with scissors and tape removed; cup inverted over glass vial and compressed to eject frozen pellet.

dropper (Cooke Engineering Co., Alexandria, Virginia, USA) and the trays sealed with adhesive plastic tape before storage. A portion of each culture was stored also in a glass vial of $c .2 \mathrm{ml}$. After thawing and testing, no culture was re-stored.

Low temperature storage. Cultures were stored in electrically operated cabinets at $-70^{\circ} \mathrm{C}$ and $-50^{\circ} \mathrm{C}$ (V. M. Berry, Refrigeration Engineers, Liverpool) and $-30^{\circ} \mathrm{C}$ (Helimatic Ltd, 419 Oxford Street, London).

Lyophilisation. Cultures in liquid medium were mixed with an equal volume of one of the following stabilising fluids: (i) skim milk; (ii) an aqueous solution of $10 \mathrm{~g}$ dextrose and $10 \mathrm{~g}$ dextran per $100 \mathrm{ml}$ (dextrose-dextran); or (iii) a 2 per cent. solution in liquid medium of bovine plasma albumin (BPA). Then $0 \cdot 1-\mathrm{ml}$ amounts of the particular mixture were dispensed in glass ampoules and dried for about 1 day on an Edwards model 5PS centrifugal freeze-drier (Edwards High Vacuum Ltd, Crawley, Sussex). The ampoules were sealed at a final vacuum of less than 20 torr $\left(270 \mathrm{Nm}^{-2}\right)$. Samples of each batch were stored in parallel at $4{ }^{\circ} \mathrm{C}$ and $37^{\circ} \mathrm{C}$ and the presence of a vacuum confirmed with a high-frequency tester before the ampoules were opened for titration of their contents (Tyrrell and Ridgewell, 1965). 


\section{RESULTS}

Comparison of viability after storage in glass vials and plastic trays

The titres of viable organisms in cultures of six serologically different mycoplasmas after storage at $-70^{\circ} \mathrm{C}$ are shown in table I. As might be expected with titrations performed in serial 10 -fold dilutions, titres on two or more aliquots of the same culture apparently varied by more than $1 \log _{10}$. However, it appeared that the titre of viable organisms did not diminish much over a

TABLE I

Viability of mycoplasma organisms stored in glass vials or plastic trays at $-70^{\circ} \mathrm{C}$ for $24 \mathrm{mth}$

\begin{tabular}{|c|c|c|c|c|}
\hline \multirow{2}{*}{ Mycoplasma strain tested } & \multirow{2}{*}{$\begin{array}{l}\text { Storage in } \\
\text { vial }(\mathrm{V}) \\
\text { or tray }(\mathrm{T})\end{array}$} & \multicolumn{3}{|c|}{$\log _{10}$ titres* after } \\
\hline & & $3 \mathrm{mth}$ & $6 \mathrm{mth}$ & $24 \mathrm{mth}$ \\
\hline M. arthritidis (PG27) & $\begin{array}{l}\mathrm{V} \\
\mathrm{T}\end{array}$ & $\begin{array}{c}6 \\
5,6\end{array}$ & $5,5, \frac{7}{6,6}, 7,7$ & $5, \frac{6}{5,6}$ \\
\hline M. hominis (PG21) & $\begin{array}{l}\mathrm{V} \\
\mathrm{T}\end{array}$ & $\begin{array}{c}7,8,8,9 \\
9,10\end{array}$ & $\begin{array}{c}\mathrm{NT} \\
7,8,8,8\end{array}$ & $\stackrel{8}{7,8}$ \\
\hline M. orale type I (CH19299) & $\begin{array}{l}\mathrm{V} \\
\mathrm{T}\end{array}$ & $\begin{array}{r}7,8 \\
7,8,8,8,8,8\end{array}$ & $\begin{array}{l}\mathrm{NT} \\
8,8\end{array}$ & $\stackrel{8}{7,9}$ \\
\hline M. pneumoniae $(\mathrm{FH})$ & $\begin{array}{l}\mathrm{V} \\
\mathrm{T}\end{array}$ & $6,7,7$ & $\begin{array}{l}\text { NT } \\
6,7\end{array}$ & $5,5,6,7$ \\
\hline M. salivarium (PG20) & $\begin{array}{l}\mathrm{V} \\
\mathrm{T}\end{array}$ & $5,6,6,6,7,7,8$ & $\begin{array}{l}9 \\
6,6,8\end{array}$ & $\begin{array}{r}5 \\
5,5,6\end{array}$ \\
\hline T-strain (human; REOW) & $\begin{array}{l}\mathrm{V} \\
\mathrm{T}\end{array}$ & $6,6,6$ & $\begin{array}{l}\text { NT } \\
\text { NT }\end{array}$ & $5,5,6$ \\
\hline
\end{tabular}

* Titrations on one or more samples at indicated time. NT $=$ Not tested.

period of $24 \mathrm{mth}$, whether they were stored in glass vials or plastic trays. For more accurate results in subsequent experiments, titration of a single aliquot of a culture was performed in triplicate in liquid medium or by colony counts on solid medium.

\section{Storage at different temperatures}

Storage at $-70^{\circ} \mathrm{C}$. Cultures were routinely stored at this temperature. The viability of strains stored for periods of up to $42 \mathrm{mth}$ is shown in table II. The viability titres of only three strains fell by as much as $1 \log _{10}$.

Storage at $-50^{\circ} \mathrm{C}$. Portions of cultures of four mycoplasmas of human origin, namely $M$. hominis, $M$. orale type $\mathrm{I}, M$. pneumoniae and $\mathrm{T}$-strain REOW were transferred from $-70^{\circ} \mathrm{C}$ to $-50^{\circ} \mathrm{C}$ and kept there for $2 \mathrm{yr}$. Over this period of time the viability titres of the materials stored at $-50^{\circ} \mathrm{C}$ were the same as those of materials remaining at $-70^{\circ} \mathrm{C}$.

Storage at $-30^{\circ} \mathrm{C}$. Samples of cultures of three mycoplasmas were held in parallel at $-30^{\circ} \mathrm{C}$ and at $-70^{\circ} \mathrm{C}$, in order to determine whether the higher temperature was useful for storage. The cultures were titrated at intervals over 
a period of 2 yr and during this time it appeared that the titres of viable organisms stored at the higher temperature were not different from those of organisms stored at the lower temperature.

TABLE II

Viability of various mycoplasmas stored in plastic trays at $-70^{\circ} \mathrm{C}$

\begin{tabular}{|c|c|c|c|c|c|}
\hline \multirow{2}{*}{ Mycoplasma strain tested } & \multicolumn{4}{|c|}{$\log _{10}$ mean titre* after } & \multirow{2}{*}{$\begin{array}{l}\text { Reduction in! } \\
\text { viable titre of } \\
\text { more than } 1 \log _{10} \\
\text { by } 38-42 \mathrm{mth}\end{array}$} \\
\hline & $\begin{array}{l}1-9 \\
\text { mth }\end{array}$ & $\begin{array}{l}10-18 \\
\text { mth }\end{array}$ & $\begin{array}{l}19-27 \\
\text { mth }\end{array}$ & $\begin{array}{l}38-42 \\
\text { mth }\end{array}$ & \\
\hline $\begin{array}{l}\text { M. arthritidis (PG27) } \\
\text { M. bovigenitalium (PG11) } \\
\text { M. fermentans (PG18) } \\
\text { M. gallisepticum (S6) } \\
\text { M. granularum } \\
\text { M. hominis (PG21) } \\
\text { M. hominis (V2785) } \\
\text { M. hyorhinis (F) } \\
\text { M. hyorhinis (GDL) } \\
\text { M. laidlawii A (PG8) } \\
\text { M. orale type I (CH19299) } \\
\text { M. orale type II (CH20247) } \\
\text { M. pneumoniae (FH) } \\
\text { M. pulmonis (Negroni) } \\
\text { M. salivarium (PG20) } \\
\text { T-strain (human; REOW) }\end{array}$ & $\begin{array}{l}5 \cdot 9 \\
6 \cdot 0 \\
4 \cdot 7 \\
8 \cdot 6 \\
6 \cdot 0 \\
8 \cdot 3 \\
7 \cdot 3 \\
(8) \\
7 \cdot 2 \\
7 \cdot 0 \\
7.9 \\
6 \cdot 4 \\
6 \cdot 6 \\
7 \cdot 8 \\
6 \cdot 5 \\
6.0\end{array}$ & $\begin{array}{l}(7) \dagger \\
5 \cdot 0 \\
(6) \\
(7) \\
(7) \\
8 \\
5 \cdot 7 \\
(8) \\
(7) \\
(8) \\
(7) \\
(6) \\
(6) \\
(8) \\
3 \cdot 7 \\
5 \cdot 0\end{array}$ & $\begin{array}{l}5 \cdot 3 \\
5 \cdot 5 \\
5 \cdot 5 \\
7 \cdot 7 \\
(6) \\
7 \cdot 7 \\
6 \cdot 3 \\
(8) \\
6 \cdot 5 \\
(7) \\
7 \cdot 5 \\
6 \cdot 7 \\
6 \cdot 2 \\
7 \cdot 7 \\
5 \cdot 5 \\
5 \cdot 3\end{array}$ & $\begin{array}{l}5 \cdot 6 \\
5 \cdot 6 \\
5 \cdot 9 \\
7 \cdot 7 \\
7 \cdot 4 \\
7 \cdot 9 \\
6 \cdot 1 \\
8 \cdot 5 \\
7 \cdot 2 \\
7 \cdot 5 \\
7 \cdot 9 \\
7 \cdot 0 \\
6 \cdot 7 \\
6 \cdot 6 \\
5 \cdot 0 \\
5 \cdot 8\end{array}$ & $\begin{array}{l}\bar{z} \\
\bar{z} \\
= \\
\overline{+} \\
\pm \\
= \\
= \\
= \\
\overline{+} \\
\pm \\
\pm\end{array}$ \\
\hline
\end{tabular}

* Each figure is the result of titration of 2 or more samples or of 1 sample on solid medium.

$\dagger()=$ Result of one titration only.

TABLE III

Loss of viability of mycoplasmas stored at $-30^{\circ} \mathrm{C}$ or $-70^{\circ} \mathrm{C}$ for $27 \mathrm{mth}$

\begin{tabular}{|c|c|c|}
\hline \multirow{2}{*}{ Mycoplasma strain tested } & \multicolumn{2}{|c|}{ Loss in $\log _{10}$ titre during $27 \mathrm{mth}$} \\
\hline & at $-70^{\circ} \mathrm{C}$ & at $-30^{\circ} \mathrm{C}$ \\
\hline $\begin{array}{l}\text { M. arthritidis (PG27) } \\
\text { M. fermentans (PG18) } \\
\text { M. hominis (PG21) } \\
\text { M. hominis (V2785) } \\
\text { M. hyorhinis (GDL) } \\
\text { M. orale type I (CH19299) } \\
\text { M. orale type II (CH20247) } \\
\text { M. pneumoniae (FH) } \\
\text { M. pulmonis (Negroni) } \\
\text { M. salivarium (PG20) } \\
\text { T-strain (human; REOW)* }\end{array}$ & $\begin{array}{l}0 \cdot 5 \\
0 \\
0 \\
0 \\
0 \\
0 \\
0 \\
0 \\
1 \\
0 \\
0\end{array}$ & $\begin{array}{l}1 \cdot 5 \\
2 \\
2 \\
1 \\
0 \cdot 5 \\
0 \cdot 5 \\
2 \\
1 \\
1 \\
1 \\
0\end{array}$ \\
\hline
\end{tabular}

* Results $15 \mathrm{mth}$ after transfer from $-70^{\circ} \mathrm{C}$ to $-30^{\circ} \mathrm{C}$.

The persistence of high titres of viable organisms after a few months' storage at $-30^{\circ} \mathrm{C}$ led us to transfer part of 11 stock cultures from $-70^{\circ} \mathrm{C}$ to $-30^{\circ} \mathrm{C}$. There was no evidence that the transfer itself caused death of the organisms. 
The cultures and their loss in viability on continued storage at these two temperatures for $27 \mathrm{mth}$ are shown in table III. Titrations were done on solid media. Compared with the titres of comparable material remaining at $-70^{\circ} \mathrm{C}$, the viability titres of seven of the mycoplasmas after storage at $-30^{\circ} \mathrm{C}$ for $27 \mathrm{mth}$ had fallen by at least $1 \log _{10}$, but by not more than $2 \log _{10}$.

\section{Lyophilisation and storage}

Effect of stabiliser. M. orale type 1 (CH19299) was grown in liquid medium and aliquots were harvested after incubation for $24 \mathrm{hr}$ and $48 \mathrm{hr}$ at $36^{\circ} \mathrm{C}$.

TABLE IV

Effect of "stabilising" substance on the viability of $M$. orale type I (CH19299) during the process of freeze-drying $(F D)$ and on this material kept thereafter at $37^{\circ} \mathrm{C}$

\begin{tabular}{|c|c|c|c|c|c|c|c|c|}
\hline \multirow{4}{*}{$\begin{array}{l}\text { " Stabilising " } \\
\text { substance } \\
\text { added* }\end{array}$} & \multicolumn{8}{|c|}{$\log _{10}$ titre of mycoplasma culture, incubated, before FD, for } \\
\hline & \multicolumn{4}{|c|}{$24 \mathrm{hr}$} & \multicolumn{4}{|c|}{$48 \mathrm{hr}$} \\
\hline & \multirow{2}{*}{ before FD } & \multicolumn{3}{|c|}{$\begin{array}{l}\text { when reconstituted } \\
\text { at time after FD } \\
\text { (mth) }\end{array}$} & \multirow{2}{*}{ before FD } & \multicolumn{3}{|c|}{$\begin{array}{l}\text { when reconstituted } \\
\text { at time after FD } \\
\text { (mth) }\end{array}$} \\
\hline & & 0 & 1 & 24 & & 0 & 1 & 24 \\
\hline $\begin{array}{l}\text { Medium only } \\
\text { Bovine plasma albumin } \\
\text { Skim milk } \\
\text { Dextrose-dextran }\end{array}$ & $\begin{array}{l}9 \cdot 0 \\
8 \cdot 5 \\
9 \cdot 5 \\
9 \cdot 0\end{array}$ & $\begin{array}{l}7.5 \\
7.5 \\
8.5 \\
8.0\end{array}$ & $\begin{array}{l}\text { NT } \\
7.5 \\
6.5 \\
0\end{array}$ & $\begin{array}{l}7 \\
7 \\
3 \\
0\end{array}$ & $\begin{array}{l}8 \cdot 5 \\
8 \cdot 25 \\
8 \cdot 25 \\
8 \cdot 5\end{array}$ & $\begin{array}{l}6 \cdot 5 \\
7 \cdot 0 \\
7 \cdot 25 \\
7 \cdot 0\end{array}$ & $\begin{array}{c}5 \cdot 0 \\
6 \cdot 0 \\
5 \cdot 0 \\
0\end{array}$ & $\begin{array}{l}4 \\
5 \\
0 \\
0\end{array}$ \\
\hline
\end{tabular}

Before freeze-drying these aliquots were diluted with an equal volume of one of the "stabilising" substances (see Materials) or liquid mycoplasma medium. Titrations of viable organisms were made in triplicate before and immediately after freeze-drying and the results are shown in table IV. A decrease in titre of 1-2 $\log _{10}$ occurred during the process of lyophilising all the mixtures. It was clear that none of the additives, with the possible exception of BPA, was useful for preserving viable organisms during the process of freeze-drying.

To determine the efficiency of lyophilisation as a long-term means of preservation, the freeze-dried cultures of $M$. orale type I, with additives, were kept at $37^{\circ} \mathrm{C}$ and titrated for viable organisms after $1 \mathrm{mth}$ and $2 \mathrm{yr}$ at this temperature (table IV). The organisms were preserved almost equally well in medium alone or in medium with BPA, whereas those in medium with skim milk or in medium with " dextrose-dextran " were killed, in the case of the latter after $1 \mathrm{mth}$. In addition, organisms that were harvested and dried after $24 \mathrm{hr}$ were more resistant than those similarly treated after incubation for $48 \mathrm{hr}$.

Long-term storage at $4^{\circ} \mathrm{C}$ and $37^{\circ} \mathrm{C}$. Subsequently, another ten mycoplasma 
cultures were prepared in liquid medium. In an attempt to avoid incubating them beyond the time of maximum viability, cultures were placed at $4^{\circ} \mathrm{C}$ when the $p \mathrm{H}$ of the medium had changed by no more than one $p \mathrm{H}$ unit. As soon as possible thereafter an equal volume of 2 per cent. BPA was added and the cultures were freeze-dried. Samples of each lyophilised culture were stored in parallel at $4^{\circ} \mathrm{C}$ and $37^{\circ} \mathrm{C}$ and they were titrated for viable organisms at various

\section{TABLE V}

Viability of mycoplasma organisms before and after freeze-drying (FD) and during subsequent storage at $4^{\circ} \mathrm{C}$ or $37^{\circ} \mathrm{C}$

\begin{tabular}{|c|c|c|c|c|c|c|}
\hline \multirow{2}{*}{$\begin{array}{l}\text { Mycoplasma } \\
\text { strain tested }\end{array}$} & \multirow{2}{*}{$\begin{array}{c}\text { Titre } \\
\left(\log _{10}\right) \\
\text { before } \\
\text { FD }\end{array}$} & \multirow{2}{*}{$\begin{array}{l}\text { Storage } \\
\text { temp. } \\
\left({ }^{\circ} \mathrm{C}\right)\end{array}$} & \multicolumn{4}{|c|}{ Titre $\left(\log _{10}\right)$ after FD and storage for } \\
\hline & & & $0 \mathrm{mth}$ & $12-15 \mathrm{mth}$ & $18-21 \mathrm{mth}$ & $27-34 \mathrm{mth}$ \\
\hline $\begin{array}{l}\text { M. fermentans } \\
\text { (PG18) }\end{array}$ & 8 & $\begin{array}{r}4 \\
37\end{array}$ & $\begin{array}{c}6 \\
\cdots\end{array}$ & $\begin{array}{l}5 \\
3\end{array}$ & $\begin{array}{l}6 \\
3\end{array}$ & $\begin{array}{l}6 \\
2\end{array}$ \\
\hline $\begin{array}{l}M \text {. gallisepticum } \\
\text { (S6) }\end{array}$ & 7 & $\begin{array}{r}4 \\
37\end{array}$ & $\begin{array}{l}7 \\
\cdots\end{array}$ & $\begin{array}{l}7 \\
4\end{array}$ & $\begin{array}{l}\ldots \\
\cdots\end{array}$ & $\begin{array}{l}5 \\
0\end{array}$ \\
\hline $\begin{array}{l}\text { M. hominis } \\
\text { (PG21) }\end{array}$ & 8 & $\begin{array}{r}4 \\
37\end{array}$ & $\begin{array}{l}6 \\
\cdots\end{array}$ & $\begin{array}{l}6 \\
6\end{array}$ & $\begin{array}{l}7 \\
\cdots\end{array}$ & $\begin{array}{c}7 \\
\cdots\end{array}$ \\
\hline $\begin{array}{l}\text { M. hyorhinis } \\
\text { (S7) }\end{array}$ & 8 & $\begin{array}{r}4 \\
37\end{array}$ & $\begin{array}{l}4 \\
\cdots\end{array}$ & $\begin{array}{l}6 \\
4\end{array}$ & $\begin{array}{l}\ldots \\
\ldots\end{array}$ & $\begin{array}{l}7 \\
2\end{array}$ \\
\hline $\begin{array}{l}M \text {. orale type I } \\
(\mathrm{CH} 19299)\end{array}$ & 9 & $\begin{array}{r}4 \\
37\end{array}$ & $\begin{array}{c}8 \\
\cdots\end{array}$ & $\begin{array}{l}7 \\
6\end{array}$ & $\begin{array}{l}\cdots \\
\cdots\end{array}$ & $\begin{array}{l}7 \\
\cdots\end{array}$ \\
\hline $\begin{array}{l}\text { M. orale type II } \\
(\mathrm{CH} 20247)\end{array}$ & 9 & $\begin{array}{r}4 \\
37\end{array}$ & $\begin{array}{l}6 \\
\cdots\end{array}$ & $\begin{array}{l}6 \\
6\end{array}$ & $\begin{array}{l}6 \\
4\end{array}$ & $\begin{array}{l}6 \\
0\end{array}$ \\
\hline $\begin{array}{l}\text { M. pneumoniae } \\
\text { (FH) }\end{array}$ & 7 & $\begin{array}{r}4 \\
37\end{array}$ & $\begin{array}{c}6 \\
\cdots\end{array}$ & $\begin{array}{l}3 \\
2\end{array}$ & $\begin{array}{l}6 \\
0\end{array}$ & $\begin{array}{l}5 \\
0\end{array}$ \\
\hline $\begin{array}{l}\text { M. salivarium } \\
\text { (PG20) }\end{array}$ & 8 & $\begin{array}{r}4 \\
37\end{array}$ & $\begin{array}{l}7 \\
\cdots\end{array}$ & $\begin{array}{l}7 \\
5\end{array}$ & $\begin{array}{l}8 \\
4\end{array}$ & $\begin{array}{l}7 \\
\cdots\end{array}$ \\
\hline $\begin{array}{l}\text { T-strain } \\
\text { (human; REOW) }\end{array}$ & 5 & $\begin{array}{r}4 \\
37\end{array}$ & $\begin{array}{l}3 \\
\cdots\end{array}$ & $\begin{array}{l}\cdots \\
\cdots\end{array}$ & $\begin{array}{l}4 \\
4\end{array}$ & $\begin{array}{l}3 \\
2\end{array}$ \\
\hline $\begin{array}{l}\text { T-strain } \\
\text { (bovine; U8) }\end{array}$ & 3 & $\begin{array}{r}4 \\
37\end{array}$ & $\begin{array}{l}4 \\
\cdots\end{array}$ & $\begin{array}{l}3 \\
3\end{array}$ & $\begin{array}{l}\cdots \\
\cdots\end{array}$ & $\begin{array}{l}4 \\
1\end{array}$ \\
\hline
\end{tabular}

times up to $34 \mathrm{mth}$ (table $\mathrm{V}$ ). The titres of viable organisms in six of the freezedried cultures were diminished after they had been stored at $37^{\circ} \mathrm{C}$ for 12 $15 \mathrm{mth}$. After 27-34 mth, viable organisms were not recoverable from three of these cultures. On the other hand, the titres of viable organisms remained undiminished in seven of the ten freeze-dried cultures that were stored at $4{ }^{\circ} \mathrm{C}$ and tested at periods varying between 27 and $34 \mathrm{mth}$.

\section{Discussion}

Kelton (1964) observed that there was no loss or only a slight loss $\left(0.5 \log _{10}\right)$ in the number of viable organisms during storage of ten mycoplasma strains of avian origin over a $12-\mathrm{mth}$ period at $-65^{\circ} \mathrm{C}$. Our results with mycoplasmas 
derived from a greater variety of sources and tested after storage at $-70^{\circ} \mathrm{C}$ over a longer period of time support such findings. Minor variations in the results of titrations performed over a period of $3 \frac{1}{2}$ yr must be expected, since not only may the number of viable mycoplasma organisms diminish but the medium used in titrations may vary in its ability to support growth. Throughout the study, however, we have used individual medium components that were each derived from a single source and we have not been aware of any major changes in the sensitivity of different batches of our medium. The nature of the medium is important because its high protein content is probably responsible for the stability of mycoplasmas over a long period of time. Certainly, media other than that described in this report and containing less native protein seem less able to keep organisms alive even at $-80^{\circ} \mathrm{C}$ (Gentry, Kantor and Marthouse, 1967).

Edward (1954) found that $-20^{\circ} \mathrm{C}$ was well tolerated by mycoplasmas and permitted storage for at least 10-12 $\mathrm{mth}$, and Kelton recovered viable organisms from cultures stored at $-26^{\circ} \mathrm{C}$ for this length of time. Cordy and Adler (1960) reported that a mycoplasma isolated from a goat was virulent after $4 \mathrm{yr}$ at $-20^{\circ} \mathrm{C}$. Further, Switzer (1967) reported that $M$. hyopneumoniae could be stored at $-25^{\circ} \mathrm{C}$ in pneumonic pig lung tissue for "long periods of time". However, in none of these studies were quantitative estimations made to detect a possible decrease in the numbers of organisms. Hayflick and Stinebring (1960) stored avian and murine mycoplasmas in egg yolk at $-20^{\circ} \mathrm{C}$ and apparently observed only a small decrease in the number of viable organisms after 2 yr. Our results show that, compared with storage at $-70^{\circ} \mathrm{C}$, storage at $-30^{\circ} \mathrm{C}$ results in a marked decrease in the number of viable organisms after $2 \mathrm{yr}$. Thus, it does not seem advisable to store for a long period at this temperature freshly isolated material, which may contain only a few viable organisms. However, it is quite clear that $-30^{\circ} \mathrm{C}$ is an adequately low temperature for the storage of stock cultures known to have a high initial titre.

There are numerous reports of successful lyophilisation of large-colonyforming mycoplasmas (Edward, 1940; Gray and Turner, 1954; Conrad, 1958; Freundt, 1958; Smith and Sasaki, 1958; Kelton; Adler, 1965; Yamamoto, Bigland and Ortmayer, 1965) and two reports (Shepard, 1967; Taylor-Robinson et al., 1968) concerning the successful lyophilisation of T-strain mycoplasmas. Smith and Sasaki showed, not unexpectedly, that mycoplasmas did not survive lyophilisation in distilled water but did so in culture medium, although there was a $1-4 \log _{10}$ decrease in the number of viable organisms. Indeed, it seems that all workers have been unable to freeze-dry mycoplasmas without killing at least 90 per cent. of them. In general, this has been our experience too, although we did freeze-dry $M$. gallisepticum and a T-strain mycoplasma of bovine origin apparently without loss. We tested several substances that have been found useful as "stabilisers" in the freeze-drying of certain viruses (Tyrrell and Ridgewell, 1965) and bacteria. With the possible exception of BPA, which we later added as a routine, none of these was useful and some were undoubtedly harmful in subsequent long-term storage of lyophilised material. It seems from the experiments with $M$. orale type I that the use of 
organisms in their early growth phase is more important than the use of a stabiliser. However, from a practical point of view, killing of some of the organisms during the process of lyophilisation is of little consequence when the material so treated is of high titre. Those organisms that survive the procedure remain viable for years when stored at $4^{\circ} \mathrm{C}$, and it is indeed impressive that many of them do so even when stored for some years at $37^{\circ} \mathrm{C}$. It seems that if mycoplasmas could be completely dried in medium containing much serum protein, they would remain viable indefinitely. The failure to recover organisms from an ampoule of freeze-dried material may be due to incomplete drying, an imperfect sealed ampoule or use of a recovery medium that is inadequate for growth of the organisms.

\section{SUMMARY}

Fourteen serologically distinct mycoplasmas from various avian and mammalian sources were stored frozen in liquid medium. At $-70^{\circ} \mathrm{C}$, the number of viable organisms of only three of these mycoplasmas decreased by $1 \log _{10}$ after $3 \frac{1}{2}$ yr. Four of the same mycoplasmas of human origin were stored at $-50^{\circ} \mathrm{C}$ and the number of viable organisms remained undiminished after $2 \mathrm{yr}$. On the other hand, at $-30^{\circ} \mathrm{C}$ the viability titres of 8 of 11 mycoplasmas decreased by at least $1 \log _{10}$, but by no more than $2 \log _{10}$ after a similar period of time. Lyophilisation caused an immediate decrease in the number of viable organisms of most but not all mycoplasmas so treated. The addition of several " stabilising" fluids, used in the lyophilisation of viruses and bacteria, was not helpful. These had no immediate protective effect and some of them rapidly killed the organisms during subsequent storage. Cultures of ten mycoplasmas in liquid medium containing 2 per cent. bovine plasma albumin were lyophilised and samples of each lyophilised culture were stored in parallel at $37^{\circ} \mathrm{C}$ and at $4^{\circ} \mathrm{C}$. They all contained viable organisms after storage at $37^{\circ} \mathrm{C}$ for 15-18 mth; of 7 cultures tested after $27-34 \mathrm{mth}, 4$ of them still contained viable organisms. All the lyophilised cultures stored at $4{ }^{\circ} \mathrm{C}$ contained viable organisms, seven of them in undiminished numbers, after 27-34 mth.

We are grateful to Professor K. Dumbell for the use of the $-50^{\circ} \mathrm{C}$ refrigerator in his department and we thank Mrs Beverley Head and Mrs Susan Beveridge for technical assistance.

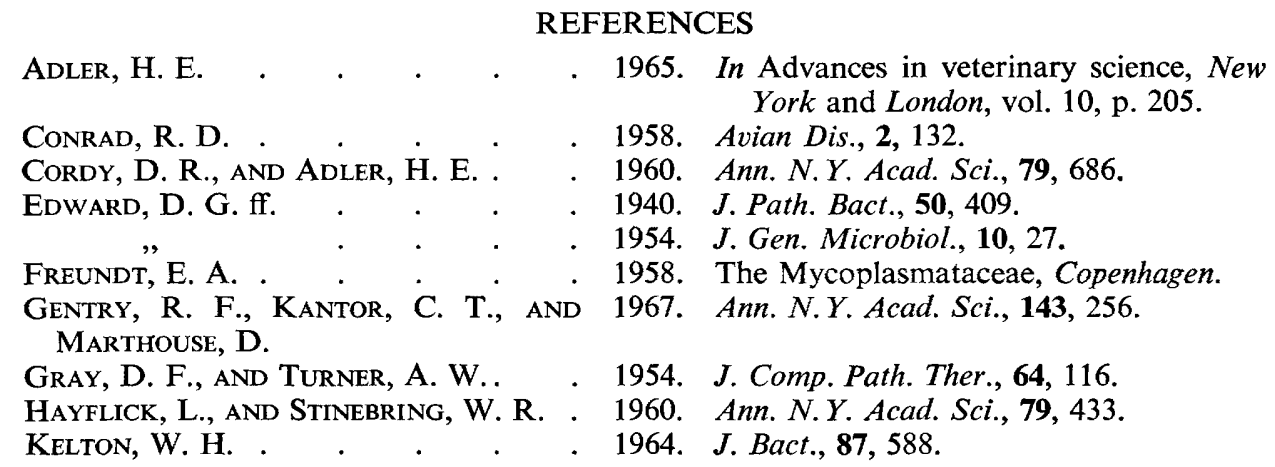


Manchee, R. J., AND TAYlor-Robinson, 1968. J. Gen. Microbiol., 50, 465.

D.

Shepard, M. C. . . . . . . . 1967. Ann. N.Y. Acad. Sci., 143, 505.

SMIth, P. F., ANd SaSaki, S. . $\quad$. $\quad$ 1958. Appl. Microbiol., 6, 184.

Switzer, W. P. . . · · . 1967. Ann. N.Y. Acad. Sci., 143, 281.

TAylor-Robinson, D., Williams, M. H., 1968. J. Gen. Microbiol., 54, 33. AND Haig, D. A.

Tyrrell, D. A. J., AND Ridgewell, B. . 1965. Nature, Lond., 206, 115.

Yamamoto, R., Bigland, C. H., AND 1965. J. Bact., $90,47$.

ORTMAYER, H. B. 